\title{
IMPLEMENTASI PENDIDIKAN INKLUSIF DI MADRASAH IBTIDAIYAH DI JAWA TIMUR
}

\author{
Mochamad Syaifudin 1 \\ IIAI AI Khoziny Sidoarjo
}

\begin{abstract}
ABSTRAK
Banyak madrasah yang menyelengarakan pendidikan inklusif, namun belum mendapatkan pengakuan legal formal dari pemerintah. Sehingga dalam proses operasinalnya tidak berjalan secara optimal. Oleh sebab itu, penelitian ini berupaya untuk menganalisis implementasi pendidikan inklusif di Jawa Timur dengan lokus MI Badrus Salam Surabaya, MINU Miftahul Ulum 91 Plinggisan Kraton Pasuruan dan MI Terpadu Ar-Roihan Malang. Ketiganya dipilih karena telah mendapatkan izin operasional untuk menyelenggarakan pendidikan inklusif sejak tahun 2016. Jenis penelitian yang digunakan adalah kualitatif-deskriptif dengan metode pengumpulan data yaitu observasi partisipan, wawancara mendalam dan dokumentasi. Dari penelitian ini, dapat diambil kesimpulan yaitu: pertama Implementasi pendidikan inklusif di MI Badrus Salam Surabaya, MINU Miftahul Ulum 91 Plinggisan Kraton Pasuruan dan MI Terpadu Ar-Roihan Malang sangat baik dalam hal kurikulum pembelajaran dan penciptaan lingkungan ramah inklusif. Dalam penyediaan GPK dengan rasio ABK, hanya MI Terpadu ArRoihan Malang yang ideal dibandingkan 2 madrasah lain. Kedua, pendidikan inklusif sangat bermakna bagi stakeholder di tiga lembaga tersebut. Ini dibuktikan adanya dukungan maksimal dari kepala madrasah, guru, pemerintah (dalam hal ini Kementerian Agama), dunia usaha dan dunia industri dalam penyelenggaraan program inklusi di madrasah.

Kata Kunci: Madrasah Ibtidaiyah, Pendidikan Inklusif, Kurikulum, Humanisme.

\section{ABSTRACT}

Many madrasas provide inclusive education, but have not yet received formal legal recognition from the government. So that the operational process is not implemented optimally. Therefore, this study attempts to analyze the implementation of inclusive education in East Java with the locus of MI Badrus Salam Surabaya, MINU Miftahul Ulum 91 Plinggisan Kraton Pasuruan and MI Terpadu Ar-Roihan Malang. The three were chosen because they have received operational permits to provide inclusive education since 2016. The type of research used was qualitative-descriptive with data collection methods, namely participant observation, in-depth interviews and documentation. From this research, it can be concluded that: firstly, the implementation of inclusive education at MI Badrus Salam Surabaya, MINU Miftahul Ulum 91 Plinggisan Kraton Pasuruan and MI Terpadu Ar-Roihan Malang is very good in terms of learning curriculum and creating an inclusive friendly environment. In providing GPK with ABK ratio, only MI Terpadu Ar-Roihan Malang is ideal compared to 2 other madrasas. Second, inclusive education is very meaningful for stakeholders in the three institutions. This is evidenced by the maximum support from madrasa heads, teachers, the government (in this case the Ministry of Religion), the business world and the industrial world in implementing inclusion programs in madrasas.

Keywords: Madrasah Ibtidaiyah, Inclusive Education, Curriculum, Humanism.
\end{abstract}

\section{A. Pendahuluan}

Pendidikan dipahami sebagai usaha sadar dan terencana untuk mewujudkan suasana belajar dan proses pembelajaran agar peserta didik dapat mengembangkan potensi yang dimilikinya. ${ }^{1}$ Pendidikan merupakan salah satu hak dasar asasi manusia yang dijamin dan dilindungi, seperti tercantum dalam UUD 1945 pasal 31 ayat 1 diamanatkan bahwa setiap warga negara mempunyai kesempatan yang sama untuk memperoleh pendidikan. ${ }^{2} \mathrm{Hal}$ ini berarti semua orang dapat mengenyam pendidikan

\footnotetext{
1 UU RI Nomor 20 Tahun 2003 tentang Sistem Pendidikan Nasional.
}

${ }^{2}$ UUD 1945 pasal 31 ayat 1 
tidak terkecuali mereka yang memiliki kelainan fisik, emosional, mental, intelektual, dan/atau sosial.

Selanjutnya dalam Pasal 32 dalam UU RI Nomor 20 Tahun 2003 menyebutkan bahwa: "Pendidikan khusus (pendidikan luar biasa) merupakan pendidikan bagi peserta didik yang memiliki tingkat kesulitan dalam mengikuti proses pembelajaran karena kelainan fisik, emosional, mental, dan sosial, dan atau memiliki potensi kecerdasan dan bakat istimewa". ${ }^{3}$ Peserta didik dengan kondisi demikian kemudian disebut dengan istilah anak berkebutuhan khusus karena dinilai lebih humanis. Selanjutnya layanan pendidikan khusus bagi anak berkebutuhan khusus terwujud dalam Sekolah Luar Biasa (SLB) yang memiliki jenjang sama dengan pendidikan reguler, mulai dari TKLB, SDLB, SMPLB, hingga SMALB. Seluruh peserta didik dalam sekolah luar biasa adalah mereka yang memiliki cacat fisik, mental atau ketunaan yang berusaha mengembangkan bakat dan potensi yang dimilikinya melalui layanan khusus. Hal ini mengakibatkan interaksi yang terjadi dalam sekolah luar biasa kurang mendukung perkembangan emosi dan sosial siswa berkebutuhan khusus. ${ }^{4}$

Kebijakan tentang pendidikan inklusif telah menjadi kesepakatan internasional, seperti tercantum dalam Declaration of Human Right (1948), juga Convention on The Right of Child (1989) yang telah diratifikasi oleh pemerintah Indonesia menjadi Education for All yang dideklarasikan di Bangkok (1991), Salamanca Statement mengenai pendidikan kebutuhan khusus (1994), Permendiknas Nomor 70 tahun 2009 tentang Pendidikan Inklusif bagi Peserta didik yang memiliki kelainan dan memiliki potensi kecerdasan dan/atau bakat istimewa, dan Undang-undang Nomor 8 Tahun 2016 tentang penyandang Disabilitas, serta Permenrristekdikti Nomor 46 Tahun 2017 tentang Pendidikan Khusus dan Pendidikan Layanan Khusus di Perguruan Tinggi. ${ }^{5}$ Di Indonesia sampai saat ini mengenal tiga model sistem pendidikan bagi anak berkebutuhan khusus, (1) model sekolah khusus sesuai dengan jenis kecacatannnya, dengan nama Sekolah Luar Biasa (SLB), (2) model sekolah terpadu sesama anak berkebutuhan khusus dengan nama Sekolah Dasar Luar Biasa (SDLB), (3) model sekolah terpadu yaitu anak berkebutuhan khusus terpilih diintegrasikan pada sekolah reguler tertentu yang telah dipersiapkan. ${ }^{6}$

\footnotetext{
3 UU RI Nomor 20 Tahun 2003, Pasal 32.

${ }^{4} \mathrm{G}$. Bossaert, et. al., "Truly included? A Literature Study Focusing on the Social Dimension of Inclusion in Education,"International Journal of Inclusive Education (2021). doi:10.1080/13603116.2011.580464.

${ }^{5}$ Budiyanto, Pengantar Pendidikan Inklusif, Berbasis Budaya Lokal (Jakarta: Prenada Media Group, 2017), Vii.

6 Ibid., Viii.
} 
Anak berkebutuhan khusus tidak dimasukkan ke dalam lembaga luar biasa. Karena ketika mereka mengenyam pendidikan di SLB maka ini akan membangun “tembok eksklusifisme”. Eksklusifisme ini telah menghambat proses saling mengenal antar peserta didik difabel dengan peserta didik non-difabel. Dengan keterlibatan di pendidikan reguler (sekolah pada umumnya) dengan penyatuan (inclusion) maka akan membuka eksklusifisme menuju inklusifisme, membangun kembali mental psikologi bagi peserta didik berkebutuhan khusus, atau program inklusi, yaitu pendidikan yang memberikan kesempatan yang sama kepada semua peserta didik termasuk yang berkebutuhan khusus untuk mendapatkan pendidikan di kelas reguler tanpa pembedaan. $^{7}$

Pendidikan inklusif menjadi alternatif pendidikan bagi anak berkebutuhan khusus yang mengalami keterbatasan fisik namun masih dapat mengikuti materi yang diajarkan di sekolah-sekolah umum. ${ }^{8}$ Banyak di antara mereka yang bersekolah di sekolah umum dapat mengikuti pembelajaran dan bahkan mampu mengalahkan anakanak yang tumbuh dengan fisik yang utuh dari materi yang diujikan kepada mereka. Dengan bergabungnya mereka di sekolah reguler (non SLB) berarti memberikan kesempatan bagi mereka untuk dapat bersosialisasi dengan anak yang tumbuh dengan normal guna membantu perkembangan emosional anak tersebut agar tidak menjadi anak yang minder, dan bahkan menganggap diri mereka sama dengan anak yang lain. Hal inilah yang mendasari pendidikan inklusif diselenggarakan. ${ }^{9}$

Karena itu menyekolahkan anak berkebutuhan khusus ke SLB bukan solusi, tetapi menjadi masalah tersendiri. Maka pilihan yang tepat adalah memasukkan mereka ke sekolah inklusif. Sejak deklarasi Salamanca Spanyol pada tahun 1994 yang memutuskan semboyan pendidikan untuk semua (education for all) yang salah satunya mengembangkan pendidikan inklusif mulai menjadi perbincangan dan diakomodir untuk membuka kesempatan bagi siapa pun manusia dengan beragam karakter dalam mendapatkan hak dasar, pendidikan. Bahwa pendidikan inklusi memiliki arti, sekolah harus mengakomodasi semua anak tanpa menghiraukan kondisi fisik, intelektual, sosial, emosional, linguistik atau kondisi lain mereka. ${ }^{10}$

\footnotetext{
7 Syamsu Huda Rohmadi, “Kurikulum Berbasis Inklusi di Madrasah”, Conference Proseding AICIS XII (2018), 65.

8 Baca, M.A. Falvey \& C.C. Givner, "What is an inclusive school?" In Villa, R.A. \& Thousand, J.S. (Eds.). Creating an inclusive school (2nd ed.) (Alexandria, Virginia: ASCD, 2005).

9 Abdul Hafiz, “Urgensi Pendidikan Inklusif bagi Anak Berkebutuhan Khusus”, Jurnal As-Salam, Vol. 1, no. 3, (2017): 1 .

10 The Salamanca Statement and Framework for Action on Special Needs Education (1994).
} 
Pendidikan Inklusif adalah sebuah dimensi dari pendidikan berbasis hak yang menekankan kesetaraan dalam akses dan partisipasi dan secara positip merespon kebutuhan belajar individual serta kompetensi seluruh anak. ${ }^{11}$ Kuncinya adalah bahwa inklusi mewujudkan anak untuk tidak mengalami diskrimasi yang merupakan salah satu prinsip dari CRC (Konvensi Hak Anak). ${ }^{12}$

Sebagaimana sejarah pendidikan di Indonesia, dalam penyelengaraan pendidikan dikelola melalui dua atap, Kementerian Pendidikan dan Kebudayaan dan Kementerian Agama. Untuk lembaga yang bernaung di bawah Kementerian Pendidikan dan Kebudayaan diawali dengan istilah "sekolah" dalam semua jenjang sedangkan Kementerian Agama dengan istilah “madrasah”. Dalam konteks madrasah, Kementerian Agama baru menformalkan pendidikan inklusif dalam bentuk surat keputusan pada tahun 2016. ${ }^{13}$

Tapi dalam praktek keseharian banyak sekali madrasah yang menerima siswa berkebutuhan khusus. Kondisi ini disebabkan karena sebaran madrasah mayoritas berada di pedesaan daripada perkotaan sehingga potensi siswa yang berkebutuhan khusus akan pendidikan yang layak lebih besar terutama karena faktor ekonomi, fasilitas dan angka putus sekolah. Dari 83.375 madrasah sampai dengan dikeluarkan surat keputusan yang ditunjuk sebagai penyelenggara pendidikan inklusi baru 22 lembaga. Untuk lima lembaga berada di Jawa Timur berdasarkan Surat Keputusan Direktorat Jenderal Pendidikan Islam nomor 3211 tahun 2016 tentang penetapan 22 (dua puluh dua) madrasah inklusif yang meliputi lima madrasah yaitu MI Badrus Salam Surabaya, MTs Wahid Hasyim Surabaya, MI Darul Ulum Rejo Sari Kraton Pasuruan, MI NU Miftahul Ulum 91 Plinggisan Kraton Pasuruan dan MI Terpadu Ar-Roihan Lawang Malang. Empat lembaga merupakan pilot project hasil kerjasama antara Kemitraan Pendidikan Autralia Indonesia (KPAl) dan Kementerian Agama sedangkan nama lembaga terakhir lebih dulu membuka layanan pendidikan inklusif walaupun dengan pembiayaan swadaya. ${ }^{14}$

Karena belum banyaknya madrasah yang mendapatkan pengakuan legal formal oleh Pemerintah dalam hal ini Kementerian Agama, maka penyelenggaraan pendidikan inklusif belum optimal, implementasi tidak mendapatkan support dari pemerintah.

11 Save The Children, Pendidikan Inklusif: Apa, Mengapa dan Bagaimana (Bandung, Yayasan Sayangi Tunas Cilik, 2016), 19.

12 Lihat Child Right Information Network (CRIN) Guide to Non-Discrimination and The CRC, Article 2, tautan pertama di bawah “More Information” https://crin.org/docs/CRC_Guide.pdf.

13 Surat Keputusan Direktorat Jenderal Pendidikan Islam nomor 3211 tahun 2016 tentang penetapan 22 (dua puluh dua) madrasah inklusif.

${ }^{14}$ https://madrasah.kemenag.go.id/gis. Diakses 13 November 2021. 
Para guru, orang tua dan masyarakat sekitar madrasah bekerjasama agar implementasi pendidikan inklusif berjalan maksimal. ${ }^{15}$

MI Badrus Salam Surabaya, sebuah madrasah yang berdiri pada tahun 1997 dengan capaian akreditasi A pada periode tahun 2019-2024. Madrasah ini berada di jantung kota Surabaya. ${ }^{16}$ Madrasah ini hanya mempunyai $1 \mathrm{GPK}$, tetapi setiap awal tahun pelajaran baru, madrasah selalu bekerjasama dengan psikolog untuk mengidentifikasi hambatan para siswa, baru setelah itu diberikan treatment khusus atau memantau perkembangan sang anak berkebutuhan khusus.

Lain halnya dengan MI NU Miftahul Ulum 91 Plinggisan Kraton Pasuruan yang berada di daerah pedesaan, dimana banyak madrasah berdiri tidak jauh dari madrasah ini, dengan mayoritas guru berjenis kelamin perempuan. Madrasah yang berdiri pada tahun 2005, ini berlokasi di Pasuruan, yang secara lingkungan mendukung pendirian lembaga pendidikan agama dengan kultur aswaja al-nahdliyah. Namun untuk menyelenggarakan pendidikan inklusif tentu tidak mudah karena membutuhkan banyak komponen pendukung selain ketersediaan sarana prasarana ramah inklusif, kurikulum juga yang tidak kalah penting ketersediaan GPK. Walaupun belum mempunyai GPK sesuai dengan kompetensi kesarjanaan, karena tuntutan dengan keberadaan siswa disabilitas, maka madrasah ini harus berbenah. ${ }^{17}$

MI Terpadu Ar-Roihan Lawang Malang ini baru berdiri pada 2008, tapi beberapa tahun terakhir, madrasah ini menjadi favorit untuk menyelenggarakan pendidikan dasar berbasis agama terutama pendidikan inklusi. ${ }^{18}$ Bahkan keterpilihan itu berdasarkan amino masyarakat sekitar untuk mendapatkan pendidikan di situ sampai harus rela inden selama 5 tahun. Tiada ketentuan khusus untuk menjadi siswa asalkan siswa masuk dalam daftar tunggu antara 1-100, maka siswa pasti akan diterima. Treatment langsung diberikan sejak siswa menginjakkan kaki di madrasah dengan bantuan tenaga psikolog, sehingga sedari awal siswa sudah teridentifikasi tentang hambatan atau pun kebutuhan selama mengenyam pendidikan di lembaga ini. Madrasah ini sudah mapan dalam penyelenggaraan pendidikan inklusif, ini ditandai dengan gagasan awal untuk menjadi lembaga inklusif sejak berdirinya sejak 2008, karena kebutuhan akan adanya model madrasah inklusif sebagai jawaban atas tuntutan masyarakat sekitar. Dinilai

${ }^{15}$ Rizza Mar'atus Sholihah, Pendidikan Inklusi di Kementerian Agama (Studi di MI Ma'arif 2 Giriloyo dan MI YAPPI Balong) (Tesis--..--. UIN Sunan Kalijaga, Yogyakarta, 2016), vii.

${ }^{16}$ Form Evaluasi Diri MI Badrus Salam Program Sosial Inklusi Kemitraan Pendidikan Australia-Indonesia, 2016.

17 Dokumen Evaluasi Madrasah MI NU Plinggisan Kraton Pasuruan Program Sosial Inklusi Kemitraan Pendidikan Australia-Indonesia.

${ }^{18}$ Wawancara dilakukan dengan Lailil Qomariyah (kepala madrasah), 21/12/21. 
mapan karena madrasah ini sudah menjadikannya sebagai program selain program yang lain. Program itu juga diketuai oleh personal yang berlatarbelakang sesuai dengan kompetensi yang diharapkan yakni; Ana Akhirul Rohmawati, S.Psi, dibantu oleh Fera Dwi Khusnani, S.Pd dan Rahmanitia Nadiatus Shalichah, S.Psi. ${ }^{19}$

Begitu kompeknya masalah dalam penyelenggaraan pendidikan inklusif. Oleh karena itu, mengemas penelitian ini dengan topik “ Implementasi Pendidikan Inklusif di Madrasah Ibtidaiyah di Jawa Timur". Penelitian ini adalah penelitian kualitatifdeskriptif. Penelitian kualitatif adalah penelitian yang menghasilkan data deskriptif berupa kata-kata tertulis atau lisan dari seseorang atau perilaku yang diamati. ${ }^{20}$ Sesuai dengan fungsi deskriptifnya, maka penelitian ini akan berupaya menjelaskan latar belakang pemikiran dan ide pimpinan tiga lembaga pendidikan Islam di Jawa Timur: MI Badrus Salam Surabaya, MI NU Miftahul Ulum 91 Plinggisan Kraton Pasuruan, dan MI Terpadu Ar-Roihan Lawang Malang. Selain itu juga, akan ada pendeskripsian kendala yang dialami dan solusi yang ditempuh dari tiga lembaga tersebut. Pendekatan penelitian ini didasarkan paradigma sosiologis-fenomenologis. ${ }^{21}$ Pendekatan sosiologis ini akan penulis gunakan untuk memetakan teritori, tempat dan domain kerja organisasinya.

\section{B. Eksistensi Pendidikan Inklusif di Madrasah}

Pendidikan merupakan hak yang dimiliki setiap warga negara tanpa terkecuali, termasuk bagi siswa difabel atau anak berkebutuhan khusus. Hak untuk mendapatkan pendidikan dijamin oleh Undang-Undang Dasar 1945 Pasal 31 Ayat 1 dan 2 yang diperkuat dengan Undang-Undang No. 20 tahun 2003 tentang Sistem Pendidikan Nasional, Pasal 5, Ayat 2, 4, dan 6 serta dikukuhkan melalui Permendiknas No. 70 Tahun 2009 Pasal 1, 2, dan 3. Diperkuat juga dengan UU No 19 Tahun 2011 tentang Pengesahan Convention on the Rights of Persons with Disabilities (Konvensi Mengenai Hak-Hak Penyandang Disabilitas) Pasal 24 Ayat 1 bahwa negara mengakui hak penyandang disabilitas atas Pendidikan.

Melalui pendidikan inklusi, siswa difabel lebih berkesempatan mendapatkan pendidikan karena mereka dapat diterima di sekolah umum bersama dengan anak non difabel di tempat yang tidak jauh dari tempat tinggalnya. Berbeda dengan sekolah luar

\footnotetext{
19 Situs resmi MIT Ar-Roihan Malang, https://mit.arroihan.sch.id/program-inklusi/, Diakses pada 02/12/21, pukul 09.45.

${ }^{20}$ Lexy J. Moleong, Metodologi Penelitian Kualitatif (Bandung: Remaja Rosdakarya, 1999), 4.

21 Lihat, YF La Kahija, Penelitian Fenomeneologis, Jalan Memahami Pengalaman Hidup (Jogjakarta: PT. Kanisius, 2017), 32.
} 
biasa yang keberadaannya agak jauh dari rumah masing-masing siswa difabel. Namun dalam realitasnya, siswa difabel masih belum bisa mendapatkan hak pendidikan sesuai dengan harapan, pendidikan secara merata dan adil, karena masih banyak kendala atau hambatan baik hambatan yang bersifat internal maupun eksternal. Hambatan internal berkaitan dengan guru reguler yang tidak siap menghadapi siswa difabel dengan alasan tidak memiliki kemampuan untuk mengajar siswa difabel maupun kendala terbatasnya Guru Pembimbing Khusus dan belum siapnya pihak sekolah untuk menerima siswa difabel. Sedang hambatan eksternal berkaitan dengan kebijakan pemerintah seperti sangat terbatas fasilitas yang memadai bagi siswa difabel untuk mendapatkan pendidikan. ${ }^{22}$

Data yang dihimpun Direktorat Sekolah Dasar Kemendikbudristek memperlihatkan kalau pada saat ini (Per September 2021) jumlah Satuan Pendidikan Penyelenggara Pendidikan Inklusif (SPPPI) jenjang SD sebanyak 17.134. ${ }^{23}$ Dari satuan pendidikan tersebut, jumlah siswa berkebutuhan khususnya ada sebanyak 57.155 siswa. Dengan demikian membangun sekolah inklusi merupakan salah satu upaya yang wajib dilakukan mengingat dua hal: pertama, masalah pendidikan bagi siswa difabel tidak dapat teratasi melalui sekolah khusus; kedua, pendidikan bagi siswa difabel sangat urgen dan berguna dalam meningkatkan potensi yang masih dimiliki serta membantu menyiapkan kemandirian dalam hidup.

Karakter pendidikan inklusif sangat terbuka dan menerima tanpa syarat anak Indonesia yang berkeinginan kuat untuk mengembangkan kreativitas dan ketrampilan mereka dalam satu wadah yang sudah direncanakan dengan matang. Karena pada dasarnya prinsip pendidikan inklusif memberikan kesempatan kepada setiap individu untuk mengembangkan potensinya melalui layanan pendidikan yang tepat. Mohammad Takdir Ilahi mengatakan bahwa karakter utama dalam penerapan pendidikan inklusif tidak bisa lepas dari keterbukaan tanpa batas dan lintas latar belakang yang memberikan kesempatan seluas-luasnya bagi setiap anak Indonesia yang memerlukan layanan pendidikan anti diskriminasi. ${ }^{24}$ Adapun ruang lingkup pendidikan khusus, pertama, Penyandang Disabilitas fisik yang meliputi terganggunya fungsi gerak, antara lain amputasi, lumpuh layu atau kaku, parapeglia, Cerebral Palsy, akibat strok, akibat kusta, dan orang kecil. Kedua, Penyandang Disabilitas Intelektual yang meliputi

22 Sulton, “Pendidikan Dasar Inklusif di Pati; Harapan dan Kenyataan”, INKLUSI: Journal of Disability Studies (2019):136.

23 https://ditpsd.kemdikbud.go.id/artikel/tag/Pendidikan-Inklusif . Diakses pada 21 Juni 2021.

24 Mohammad Takdir Ilahi, Pendidikan Inklusif: Konsep dan Aplikasi (Jogjakarta: Ar-Ruz Media, 2013 ), 37. 
terganggunya fungsi pikir karena tingkat kecerdasan di bawah rata-rata, antara lain lambat belajar, disabilitas grahita dan down syndrome. Ketiga, Penyandang Disabilitas Sensorik yang meliputi terganggunya salah satu fungsi dari panca indera antara lain disabilitas netra, disabilitas rungu, dan/disabilitas wicara. Keempat, penyandang disabilitas ganda yang meliputi Multi Disabilitas (lebih dari satu ragam disabilitas). ${ }^{25}$

Pendidikan Inklusif adalah kebersamaan untuk memperoleh pelayanan pendidikan dalam satu kelompok secara utuh bagi seluruh anak berkebutuhan khusus usia sekolah, mulai dari jenjang TK, SD, SLTP, sampai dengan SMA/SMK sederajat. ${ }^{26}$ Konsep ini adalah pengejawentahan pendidikan untuk semua (education for all), bahwa siapa pun anak manusia meski dengan latar belakang beragam harus diberi kesempatan mengenyam pendidikan. Karena pendidikan adalah hak dasar sebagaimana halnya dengan hak hidup dan hak memeluk agama atau kepercayaan tertentu. Karena itu lembaga konvensional dalam kelas reguler atau sekolah luar biasa dinilai belum mampu menjawab kebutuhan anak berkebutuhan khusus untuk mendapatkan hak pendidikan. Karena itu pendidikan inklusif dipilih untuk memberi kesempatan bagi setiap individu untuk mengembangkan diri, berinteraksi dengan sebaya dan mendapatkan pengalaman hidup yang bervariatif.

Pendidikan Inklusif merupakan implementasi pendidikan yang berwawasan multikultural yang dapat membantu peserta didik mengerti, menerima, serta menghargai orang lain yang berbeda suku, budaya, nilai, kepribadian, dan keberfungsian fisik dan psikologis. Meminjam istilah dalam kajian budaya, inilah miniatur dalam masyarakat yang disebut dengan melting pot. Masyarakat yang menampung beragam latar belakang tapi bisa saling menghargai, hidup damai dan azaz keadilan dan persamaan di hadapan hukum dijunjung tinggi. Masyarakat yang tidak menaruh curiga bila didapati adanya orang asing, karena dalam masyarakat ini dikembangkan kesadaran, bahwa kehadiran orang lain akan memperkaya harmonisasi antar anggota masyarakat. Melalui Pendidikan inklusif diharapkan anak berkebutuhan khusus dapat belajar bersama dengan anak pada umumnya agar dapat meningkatkan sosialisasi anak berkebutuhan khusus serta dapat mengembangkan potensi yang dimiliki. Pendidikan inklusif ditujukan pada semua kelompok termarginalisasi, tetapi kebijakan dan praktik inklusi penyandang cacat telah menjadi katalisasor utama untuk mengembangkan pendidikan inklusif yang efektif, fleksibel, dan tanggap terhadap keanekaragaman gaya dan kecepatan belajar.

${ }^{25}$ https://pmpk.kemdikbud.go.id/pendidikan-khusus/, diakses 14 November 202115.00 WIB.

${ }^{26}$ Dini Subini, Pengembangan Pendidikan Inklusi Berbasis Potensi (Jogjakarta: Maxima, 2004), 50. 
Walaupun secara kelembagaan terwadahi dalam sekolah inklusif, lalu yang menjadi persoalan bagaimana proses pembelajaran dijalankan. Bagaimana kurikulum didesain. Bagaimana evaluasi dilakukan. Untuk menentukan anak berkebutuhan siapa yang berwenang, apakah dilakukan secara mandiri oleh masing-masing madrasah ataukah didatangkan ahli. Dari mana pembiayaan untuk melakukan identifikasi awal. Itulah pertanyaan yang mengemuka di awal menyelenggaran pendidikan inklusi. Dalam kajian psikologi tentang kecepatan belajar dibagi menjadi tiga. Pertama, peserta didik dengan kecepatan belajar di atas rata-rata, peserta didik dengan kecepatan belajar rata-rata dan peserta didik dengan kecepatan belajar di bawah rata-rata. Untuk yang kategori pertama maka perlakuan yang harus dilakukan adalah dengan akselerasi (percepatan) dan pengayaan materi sedangkan kategori yang kedua adalah kurikulum reguler penuh, kurikulum reguler dengan modifikasi. Sedangkan kategori yang ketiga dengan empat kurikulum, yakni pertama; duplikasi yaitu kurikulum inklusi disamakan dengan kurikulum umum, kedua; modifikasi yaitu kurikulum umum dirubah untuk disesuaikan dengan kebutuhan dan kemampuan siswa, ketiga; substitusi yaitu beberapa bagain dari kurikulum umum ditiadakan tetapi diganti dengan sesuatu yang kurang lebih setara, keempat; omisi yaitu beberapa bagian dari kurikulum ditiadakan sama sekali karena tidak memungkinkan bagi $\mathrm{ABK} .{ }^{27}$

Madrasah yang berorientasi pada pengembangan kurikulum inklusi, perlu memperhatikan ciri-ciri: (1) sekolah harus menyediakan kondisi kelas yang hangat, ramah, menerima keaneka-ragaman dan menghargai perbedaan, (2) sekolah harus siap mengelola kelas yang heterogen dengan menerapkan kurikulum dan pembelajaran yang bersifat individual, (3) guru mampu membuat kurikulum adaptif yang dimaknai dalam bentuk RPP adaptif (4) guru harus menerapkan pembelajaran yang interaktif, (5) guru dituntut melakukan kolaborasi dengan profesi atau sumberdaya lain dalam perencanaan, pelaksanaan dan evaluasi, (6) guru dituntut melibatkan orang tua secara bermakna dalam proses pendidikan, dan (7) guru harus menggunakan media belajar dengan mempertimbangkan kemampuan belajar anak berkebutuhan khusus. ${ }^{28}$ Maka dari itu dalam lingkungan madrasah harus tercipta Lingkungan Inklusif Ramah Terhadap

27 Rohmadi, Kurikulum Berbasis Inklusi di Madrasah, 68-70.

28 L.M. Bullock, et., al., "Peer Relations and Socialization of Children and Adolescents with Special Needs," International Encyclopedia of Education, (2010): 794-801. https://doi.org/10.1016/B978-0-08-0448947.01131-3. 
Pembelajaran. Sebagaimana konsep di atas mengusung dua tema besar yaitu "inklusi" dan "ramah" terhadap pembelajaran. ${ }^{29}$

Dalam urusan perizinan madrasah sangat minim, sementara kebutuhan akan layanan khusus kepada anak berkebutuhan khusus harus dipenuhi. Tidak sekedar terpenuhi dengan desaian pembelajaran inklusif tapi bagaimana kepercayaan masyarakat sekitar untuk membuka identitas keluarga yang diidentifikasi berkebutuhan khusus mau meneruskan pendidikan di madrasah tersebut, belum lagi dukungan dari kalangan dunia usaha dan dunia industri, karena untuk menyelenggarakan pendidikan inklusif membutuhkan biaya besar yang tidak mungkin secara keseluruhan dibebankan pada kemampuan anggaran madrasah atau wali murid, dan seterusnya.

\section{Implementasi Pendidikan Inklusif di Madrasah Ibtidaiyah}

Jumlah anak berkebutuhan khusus yang menempuh pendidikan di MI Badrus Salam Surabaya untuk 2 tahun ajaran sebagai berikut : untuk tahun ajaran 2019/2020 sebanyak 14 siswa dan untuk tahun ajaran 2020/2021 sebanyak 13 siswa dengan keragaman kebutuhan khusus yaitu Slow Learner, ADHD, Speech Delay, Low Vision, Tunagrahita, Tunarungu. Mereka didampingi dengan 1 orang GPK. ${ }^{30}$

Jumlah anak berkebutuhan khusus yang menempuh pendidikan di MI NU Miftahul Ulum 91 Plinggisan Kraton Pasuruan untuk 2 tahun ajaran sebagai berikut : untuk tahun ajaran 2019/2020 sebanyak 5 siswa dan untuk tahun ajaran 2020/2021 sebanyak 6 dengan keragamaan kebutuhan khusus slow learner dan speech delay. Mereka didampingi oleh wali kelas masing-masing. ${ }^{31}$

Jumlah anak berkebutuhan khusus yang menempuh pendidikan di MI Terpadu ArRoihan Malang untuk 2 tahun ajaran sebagai berikut : untuk tahun ajaran 2019/2020 sebanyak 60 siswa dengan rincian kebutuhan khusus sebagai berikut tuna rungu 2 siswa, tuna netra (slow vision) 1 siswa, tuna daksa (CP, polio, cacat fisik bawaan) 8 siswa, autism 7 siswa, ADHD 20 siswa, ADD 6 siswa, down syndrom 3 siswa, slow learn 10 siswa dan dislexia 3 siswa dan untuk tahun ajaran 2020/2021 sebanyak 79 dengan keragamaan kebutuhan khusus dengan rincian sebagai berikut tuna rungu 5 siswa, tuna netra (slow vision) 1 siswa, tuna daksa (CP, polio, cacat fisik bawaan) 6 siswa, tuna wicara 2 siswa, autism 11 siswa, ADHD 28 siswa, ADD 5 siswa, down syndrom 4 siswa,

\footnotetext{
29 Magnusson Watterdal, Tulkit LIRP, Merangkul Perbedaan : Perangkat untuk Mengembangkan Lingkungan Inklusif, Ramah terhadap Pembelajaran (Jakarta: LAPIS, 2007), 1.

${ }^{30}$ Fatmah, Kepala Madrasah, Wawancara, Surabaya, 02 Desember 2021.

31 Rahma Kumala Sari, Penanggung Jawab Program Inklusi, Wawancara, Pasuruan, 03 Desember 2021.
} 
slow learn 16 siswa. Sedangkan jumlah GPK untuk tahun ajaran 2019/2020 sebanyak 43 dan 2020/2021 sebanyak 51 orang. ${ }^{32}$

Untuk layanan pendidikan yang diberikan oleh madrasah, MI Badrus Salam Surabaya yaitu penjaringan dan pengalihtanganan (identifikasi awal dan tes psikologi), bimbingan Calistung, terapi kepercayaan diri, dan terapi okupasi. ${ }^{33}$ Sedangkan untuk MI NU Miftahul Ulum 91 Plinggisan Kraton Pasuruan adalah Penjaringan dan pengalihtanganan (identifikasi awal dan tes psikologi), dan bimbingan Calistung. ${ }^{34}$ sedangkan MI Terpadu ar-Roihan Malang menggunakan 3 kurikulum antara lain : Pertama, Kurikulum Nasional : untuk ABK yang dapat mengikuti kurikulum reguler hanya ABK tersebut mempunyai hambatan di fisiknya misalnya polio atau cacat fisik bawan yang tidak mempengaruhi kognitifnya. Treatment yang diberikan bisa berupa terapi yang berhubungan motoriknya dan kemandiriannya, Kedua, kurikulum modifikasi : untuk $A B K$ yang dapat mengikuti kurikulum reguler hanya ada penurunan di $\mathrm{KD} /$ indikator di setiap mata pelajaran yang disesuaikan dengan kemampuan ABK tersebut. Kurikulum ini biasanya dipakai untuk siswa ADHD, ADD, slow learn, disleksia, austism dengan high fuction. Treatment yang diberikan disesuaikan dengan kebutuhannya misalnya untuk siswa $\mathrm{ADHD} /$ Austism ringan selain pendampingan dalam konsentrasi (fokus) ada terapi perilaku, kemandirian atau layanan kompensantoris, Ketiga, Kurikulum Adaptasi : untuk ABK yang tidak bisa mengikuti kurikulum nasional maupun kurikulum modifikasi, lebih ke terapi-terapi yang dibutuhkan. Misalnya untuk persiapan menulis, membaca dan berhitung ada terapi kognitif, motorik halus, motorik kasar, wicara, kemandirian atau layanan kompensatoris dan interaksi sosial terapi, terapi perilaku, dan lain-lain. ${ }^{35}$

Untuk menciptakan lingkungan yang ramah inklusif, MI Badrus Salam Surabaya membuat program sebagai berikut : mengubah kelas konvensional menjadi inklusif (PDBK belajar di kelas bersama teman-teman sebayanya), penyesuaian kurikulum sesuai karakteristik PDBK, menyediakan sarana prasarana untuk menunjang kegiatan pembelajaran, melibatkan partisipasi PDBK dalam kegiatan di madrasah, seperti kegiatan ekstrakurikuler dan sosialisasi mengenai keberagaman dan karakteristik PDBK. ${ }^{36}$ MI NU Miftahul Ulum 91 Plinggisan Kraton Pasuruan membuat program sebagai berikut : penyesuaian kurikulum sesuai karakteristik PDBK, menyediakan sarana

\footnotetext{
32 Rahmanitia Nadiatus Shalichah, Wawancara, Malang, 11 Desember 2021.

${ }^{33}$ Siti Badriyah, Koordinator Program Inklusi, Wawancara, Surabaya, 09 Desember 2021.

${ }^{34}$ Rahma Kumala Sari, Penanggung Jawab Program Inklusi, Wawancara, Pasuruan, 03 Desember 2021.

${ }^{35}$ Ana Akhirul Rohmawati, Program Inklusi, Wawancara, Malang, 07 Desember 2021.

${ }^{36}$ Fatmah, Kepala Madrasah, Wawancara, Surabaya, 02 Desember 2021.
} 
prasarana untuk menunjang kegiatan pembelajaran, dan melibatkan partisipasi PDBK dalam kegiatan di madrasah. ${ }^{37}$ Sementara, MI Terpadu Ar-Roihan Lawang Malang membuat program sebagai berikut : dengan melibatkan semua warga madrasah (kepala madrasah, guru kelas, guru mata pelajaran, GPK, karyawan, cleaning servise, satpam, semua siswa reguler, paguyuban, komite) untuk bekerjasama, menghormati, menyetarakan siswa berkebutuhan khusus, tidak ada pembullyan terhadap ABK, tidak ada diskriminasi, sehingga ABK mempunyai hak yang sama untuk belajar di madrasah, serta sarana dan prasarana di madrasah sudah disesuaikan dengan kebutuhan ABK. ${ }^{38}$

Dari wawancara mendalam yang dilakukan dengan kepala madrasah dan koordinator program inklusif bisa diambil kesimpulan bahwa penyelenggaraan program inklusif di MI Badrus Salam Surabaya sudah mengalami perkembangan dari yang awalnya program ini masih mengkategorikan siswa berkebutuhan khusus seiring berkembangnya waktu, mereka sudah bisa mengkategorikan ke dalam kategori yang sudah disepakati secara luas, hal yang sama juga terjadi di MI NU Miftahul Ulum 91 Plinggisan Kraton Pasuruan dan MI Terpadu Ar-Roihan Malang. Dalam pemenuhan GPK, MI Badrus Salam jauh dari ideal, hanya 1 dibandingkan dengan 14 siswa dan 13 ABK untuk 2 tahun pelajaran, MI NU Miftahul Ulum 91 Plinggisan Kraton Pasuruan malah belum mempunyai GPK sama sekali dengan rasio 5 dan 6 orang ABK, yang sangat ideal adalah di MI Terpadu Ar-Roihan Lawang Malang dengan 43 GPK untuk mendampingi 60 siswa ABK dan 51 GPK yang mendampingi 79 siswa ABK. Untuk kurikulum dan upaya dalam menciptakan lingkungan yang ramah inklusif, ketiga madrasah sudah mengupayakan dengan maksimal tentu menyesuaikan dengan kebutuhan ABK di masing-masing madrasah.

\section{Pendidikan Inklusif dan Stakeholder}

Kepala madrasah MI Badrus Salam Surabaya menjelaskan tentang hambatan dalam penyelenggaraan pendidikan inklusif di madrasah : keterbatasan GPK, tidak tersedianya ruang layanan khusus, pelaksanaan identifikasi dan tes psikologi yang belum terlaksana, tenaga pendidik masih kesulitan dalam melakukan modifikasi kurikulu, maupun asessmen akademik dan non akademik, sarana prasarana yang belum sepenuhnya aksesibel dan pemahaman orang tua mengenai kemampuan PDBK. Karena itu madrasah ingin memberikan solusi yaitu penyusunan jadwal pembelajaran, seperti jadwal pendampingan dan all out, pemanfaatan ruang kelas, laboratorium, dan

\footnotetext{
${ }^{37}$ H. Munadji, Kepala Madrasah, Wawancara, Pasuruan, 10 Desember 2021.

${ }^{38}$ Fera Dwi Khusnani, Wawancara, Malang, 08 Desember 2021.
} 
perpustakaan sebagai ruang layanan khusus, penyusunan program dan jadwal pelaksanaan identifikasi serta tes psikologi, keikutsertaan dalam pelatihan pendidikan inklusi, pemenuhan sarana prasarana secara bertahapdan sosialisasi dan kerja sama bersama orang tua untuk penyelenggaraan pendidikan inklusif. ${ }^{39}$

Kepala MI NU Miftahul Ulum 91 Plinggisan Kraton Pasuruan menyebutkan hambatannya ketiadaan GPK, tidak tersedianya ruang layanan khusus, pelaksanaan identifikasi dan tes psikologi yang belum terlaksana, tenaga pendidik masih kesulitan dalam melakukan modifikasi kurikulum, maupun asessmen akademik dan non akademik. Karena itu madrasah ingin memberikan solusi yaitu, menyediakan GPK yang memenuhi kualifikasi akademik, menggandeng psikolog untuk mengidentifikasi awal siswa $A B K$, pemanfaatan ruang kelas, dan perpustakaan sebagai ruang layanan khusus, keikutsertaan dalam pelatihan pendidikan inklusi, pemenuhan sarana prasarana secara bertahap. ${ }^{40}$

Kepala madrasah MI Terpadu Ar-Roihan menjelaskan tentang hambatan dalam penyelenggaraan pendidikan inklusif di madrasah : Guru Pembimbing Khusus tidak semua dari sarjana PLB/Psikologi, banyak yang dari guru pendidikan umum bahkan sebagian lulusan SMA/SMK sehingga madrasah memberikan pelatihan terus-menerus kepada GPK dan sulit mencari guru lulusan PLB. Sedangkan solusi yang ditawarkan adalah Untuk meningkatan SDM khususnya pengetahuan GPK yang mempunyai latar pendidikan berbeda-beda untuk menangani siswa berkebutuhan khusus, Madrasah Ar Roihan selalu menyelenggarakan pelatihan baik eksternal (mengirim GPK untuk belajar ke luar Ar Roihan, ke yayasan/sekolah penyelenggara inklusi) maupun pelatihan intern (dari guru-guru yang pernah dikirim pelatihan ke luar, untuk ditularkan atau dibagikan ke rekan-rekan GPK yang lain). Untuk meningkatkan kreatifitas guru, madrasah mengikutkan guru-guru pelatiha tentang media pembelajaran, serta madrasah juga mendatangkan narasumber yang dapat melatih guru-guru untuk giat membuat media. ${ }^{41}$

Pemerintah dalam hal ini Kementerian Agama secara berkala melakukan supervisi madrasah secara keseluruhan hanya sesekali melakukan supervisi pada program inklusi di madrasah hal yang sama juga dialami oleh MI NU Miftahul Ulum 91 Plinggisan Kraton Pasuruan. Sedangkan Ml Terpadu al-Roihan Lawang Malang ada monitoring dan evaluasi dari kemenag ke madrasah secara berkala karena madrasah ini

\footnotetext{
${ }^{39}$ Fatmah, Kepala Madrasah, Wawancara, Surabaya, 02 Desember 2021.

40 H. Munadji, Kepala Madrasah, Wawancara, Pasuruan, 10 Desember 2021.

41 Lailil Qomariyah, Kepala Madrasah, Wawancara, Malang, 06 Desember 2021. 
sudah dijadikan pilot project untuk program desiminasi program serupa di madrasah di seluruh Indonesia.

MI Badrus Salam Surabaya bekerja sama dengan pihak dunia usaha dan dunia industri sehingga peserta didik berkebutuhan khusus diberikan bekal berwirausaha melalui kegiatan entrepreneurship ABK. Pada program selanjutnya, PDBK akan diberikan keterampilan membuat karya tangan seperti membuat strip masker. Untuk MI NU Miftahul Ulum 91 Plinggisan Kraton Pasuruan kerja sama itu dilakukan dengan dunia usaha dan dunia industri dengan menjadikannya kedua pihak sebagai donatur tetap untuk membantu pendanaan program inklusi di madrasah. Sedangkan MI Terpadu alRoihan Malang dengan menjalin kerjasama dengan dunia usaha dan industri secara umum, tidak khusus untuk ABK, misalnya bantuan pemberian fasilitas wastafel, kendaraan maupun pelatihan-pelatihan untuk guru-guru.

Dari data di atas dapat disimpulkan bahwa pendidikan inklusif sangat bermakna bagi stakeholder di tiga madrasah itu. Ini dibuktikan peran serta kepala madrasah, guru, pemerintah (dalam hal ini Kementerian Agama), serta dunia usaha dan dunia industri membantu suksesnya program tersebut. Partisipasi stake holder tentu dengan kewenangan masing-masing dan bentuknya juga beragam.

\section{E. Kesimpulan}

Dari kajian yang penulis deskripsikan pada beberapa bagian sebelumnya, maka dapat diambil kesimpulan bahwa implementasi pendidikan inklusif di MI Badrus Salam Surabaya, MINU Miftahul Ulum 91 Plinggisan Kraton Pasuruan dan MI Terpadu Ar-Roihan Malang sangat baik dalam hal kurikulum pembelajaran dan penciptaan lingkungan ramah inklusif. Dalam penyediaan GPK dengan rasio ABK, hanya MI Terpadu Ar-Roihan Malang yang ideal dibandingkan 2 madrasah lain. Secara umum, pendidikan inklusif sangat bermakna bagi stakeholder di MI Badrus Salam Surabaya, MINU Miftahul Ulum 91 Plinggisan Kraton Pasuruan dan MI Terpadu Ar-Roihan Malang. Ini dibuktikan adanya dukungan maksimal dari kepala madrasah/guru, pemerintah dalam hal ini Kementerian Agama dan dunia usaha dan dunia industri dalam penyelenggaraan program inklusi di madrasah. 


\section{F. Referensi}

Bossaert, G. et. al., "Truly included? A Literature Study Focusing on the Social Dimension of Inclusion in Education."International Journal of Inclusive Education (2021). doi:10.1080/13603116.2011.580464.

Budiyanto. Pengantar Pendidikan Inklusif, Berbasis Budaya Lokal. Jakarta: Prenada Media Group, 2017.

Bullock, L.M. et., al., "Peer Relations and Socialization of Children and Adolescents with Special Needs." International Encyclopedia of Education, (2010): 794-801. https://doi.org/10.1016/B978-0-08-044894-7.01131-3.

Child Right Information Network (CRIN) Guide to Non-Discrimination and The CRC, Article 2, tautan pertama di bawah "More Information" https://crin.org/docs/CRC_Guide.pdf.

Dokumen Evaluasi Madrasah MI NU Plinggisan Kraton Pasuruan. Program Sosial Inklusi Kemitraan Pendidikan Australia-Indonesia, 2016.

Falvey, M.A. \& Givner, C.C. "What is an inclusive school?" In Villa, R.A. \& Thousand, J.S. (Eds.). Creating an inclusive school (2nd ed.). Alexandria, Virginia: ASCD, 2005.

Form Evaluasi Diri MI Badrus Salam. Program Sosial Inklusi Kemitraan Pendidikan Australia-Indonesia, 2016.

Fullan, M.G. 2007. School development: the new meaning of educational change. New York: Teachers College Press.

Hafiz, Abdul. Urgensi Pendidikan Inklusif bagi Anak Berkebutuhan Khusus, Jurnal AsSalam, Vol. 1, no. 3 (2017).

Ilahi, Mohammad Takdir. Pendidikan Inklusif: Konsep dan Aplikasi. Jogjakarta: ArRuz Media, 2013.

Kahija, YF La. Penelitian Fenomeneologis, Jalan Memahami Pengalaman Hidup. Jogjakarta: PT. Kanisius, 2017.

Marsh, C.J. Key concepts for understanding curriculum (4th ed). New York. Routledge, 2009. 
Mendikbud. Peraturan Menteri Pendidikan Nasional Nomor 70 tahun 2009 tentang Pendidikan Inklusif bagi Peserta Didik yang Memiliki Kelainan dan Memiliki Potensi Kecerdasan dan/atau Bakat Istimewa.

Moleong, Lexy J. Metodologi Penelitian Kualitatif. Bandung: Remaja Rosdakarya, 1992.

Powel, Denise Ed.D. “A Review of Inclusive Education in New Zealand.” Electronik Journal for Inclusive Education, Vol.2. No. 10 (2012):1-22.

Rohmadi, Syamsu Huda. "Kurikulum Berbasis Inklusi di Madrasah"> Conference Proseding AICIS XII (2018).

Save The Children. Pendidikan Inklusif: Apa, Mengapa dan Bagaimana. Bandung: Yayasan Sayangi Tunas Cilik, 2016.

Sholihah, Rizza Mar'atus. Pendidikan Inklusi di Kementerian Agama (Studi di MI Ma'arif 2 Giriloyo dan MI YAPPI Balong). Tesis-----UIN Sunan Kalijaga, Yogyakarta, 2016.

Smith, J. David. Inklusi, Sekolah Ramah Untuk Semua. Bandung: Nuansa, 2009.

Subini, Dini. Pengembangan Pendidikan Inklusi Berbasis Potensi. Jogjakarta: Maxima, 2014.

Sulton. "Pendidikan Dasar Inklusif di Pati; Harapan dan Kenyataan”. INKLUSI: Journal of Disability Studies (2019).

Surat Keputusan Direktorat Jenderal Pendidikan Islam nomor 3211 tahun 2016 tentang penetapan 22 (dua puluh dua) madrasah inklusif.

The Salamanca Statement and Framework for Action on Special Needs Education (1994).

UU RI Nomor 20 Tahun 2003 tentang Sistem Pendidikan Nasional.

Watterdal, Terje Magnusson. Tulkit LIRP, Merangkul Perbedaan : Perangkat untuk Mengembangkan Lingkungan Inklusif, Ramah terhadap Pembelajaran. Jakarta: LAPIS, 2007.

https://ditpsd.kemdikbud.go.id/artikel/tag/Pendidikan-Inklusif. Diakses 13 November 2021.

https://madrasah.kemenag.go.id/gis Diakses 13 November 2021.

https://madrasah.kemenag.go.id/gis/ Diakses 14 November 2021. 
https://pmpk.kemdikbud.go.id/pendidikan-khusus/ , Diakses 14 November 202115.00 WIB.

https://pmpk.kemdikbud.go.id/pendidikan-khusus/ , Diakses 14 November 202115.00 WIB.

MIT Ar-Roihan Malang, https://mit.arroihan.sch.id/program-inklusi/, Diakses pada 21/12/21, pukul 09.45 .

\section{Hasil Wawancara}

Ana Akhirul Rohmawati, Program Inklusi, Wawancara, Malang, 07 Desember 2021.

Fatmah, Kepala Madrasah, Wawancara, Surabaya, 02 Desember 2021.

Fatmah, Kepala Madrasah, Wawancara, Surabaya, 02 Desember 2021.

Fera Dwi Khusnani, Wawancara, Malang, 08 Desember 2021.

H. Munadji, Kepala Madrasah, Wawancara, Pasuruan, 10 Desember 2021.

Lailil Qomariyah, Kepala Madrasah, Wawancara, Malang, 06 Desember 2021.

Rahma Kumala Sari, Penanggung Jawab Program Inklusi, Wawancara, Pasuruan, 03 Desember 2021.

Rahmanitia Nadiatus Shalichah, Wawancara, Malang, 11 Desember 2021.

Siti Badriyah, Koordinator Program Inklusi, Wawancara, Surabaya, 09 Desember 2021. 